\title{
CONTROL OF HUMAN FILARIAL VECTOR, CULEX QUINQUEFASCIATUS (DIPTERA: CULICIDAE) THROUGH COMBINATION OF THE ENTOMOPATHO- GENIC FUNGUS, METARHIZIUM ANISOPLIAE AND NANOPARTICLES OF ZINC OXIDE AND ALUMINUM OXIDE
}

By

\author{
SALWA S. RASHED ${ }^{1 *}$, GARY W. BEALL ${ }^{2 *}$, EMAN M. RASHAD ${ }^{1}$ \\ and WAGEHA A. MOSTAFA ${ }^{1}$
}

Entomology Section, Zoology Department, Faculty of Science, Zagazig University, Egypt ${ }^{1}$ and Materials Science, Engineering \& Commercialization, Department of

Chemistry and Biochemistry, Texas State University 601 University Drive, San Marcos, TX 78666, USA ${ }^{2}{ }^{*}$ Correspondence: srashed51@hotmail.co.uk, **gb11@txstate.edu; Phone No: (512)245-8796)

\begin{abstract}
Culex quinquefasciatus (Diptera: Culicidae) is a vector of many pathogens and parasites of humans, as well as domestic and wild animals. Its eradication or control is regarded as one of the important alternative available in preventing and controlling such diseases. Thus, there is an urgent need to check the proliferation of the population of vector mosquitoes in order to reduce vector-borne diseases by appropriate control methods. This study investigated the effect of the entomopathogenic fungus, $\mathrm{Me}-$ tarhizium anisopliae against $C x$. quinquefasciatus larvae, as well as its effect when combined with zinc oxide $(\mathrm{ZnO})$ and aluminum oxide $\left(\mathrm{Al}_{2} \mathrm{O}_{3}\right)$ nanoparticles (NPs). Larvae were exposed to different concentrations of fungus, $M$. anisopliae $\left(1.42 \times 10^{5}, 1.42 \times 10^{6}, 1.42 \times 10^{7}, 1.42 \times 10^{8}\right.$ spore $\left./ \mathrm{ml}\right)$. Mortality rates of fourth instars ranged from $100 \%$ for the highest spore concentration to $80 \%$ for lowest spore concentration tested. Larvae exposed to different concentrations of $\mathrm{ZnO} \& \mathrm{Al}_{2} \mathrm{O}_{3}(5,10, \& 30 \mathrm{mg} / \mathrm{l})$ combined individually with low concentration of fungus, $M$. anisopliae, showed significantly high rates of mortality reaching $100 \%$ and $96.25 \%$ for $\mathrm{ZnO} \& \mathrm{Al}_{2} \mathrm{O}_{3}$, respectively after 4 days of treatment. SEM micrographs confirmed the attachment and penetration of the fungus $M$. anisopliae into the larval cuticle in different body parts. The combination of NPs and fungus had a synergistic effect on larvae mortality. This study showed that addition of the synthesized nano-metal oxides to $M$. anisopliae have greater efficacy on control of $C x$. quinquefasciatus larvae.
\end{abstract}

Key words: Culex quinquefasciatus, Entomopathogenic fungi, Metarhizium anisopliae, Nanoparticle metal oxides, combination effect.

\section{Introduction}

Culex quinquefasciatus Say 1823 is a domestic to peridomestic mosquito found in North America, South America, Australia, Asia, Africa, the Middle East, and New Zealand and belongs to the globally distributed $C x$. pipiens species complex which contains a number of related species, ecotypes or forms and hybrids occur along geographical introgression zones on multiple continents (CDC, 2012). Generally, Culex mosquitoes are vector many diseases as filariasis, Rift Valley Fever, West Nile Fever, Sindbis Fever, encephalitis (Elnakib et al, 2018) and widespread over large areas of the tropical and subtropical regions (Benelli et al, 2018). Control of mosquito populations is most effective when the aquatic stage is targeted because that is the most concentrated and immobile stage (Cetin et al, 2010). So, effective control measures were needed to eradicate these risky mosquitoes Using of entomopathogenic fungi and their derived products were promising approach for biological mosquitos' control (Kirschbaum, 1985). The nanotechnology is one of the most promising new approaches for pest control (Bhattacharyya et al, 2010).

With the progress of nanotechnology, many laboratories worldwide have investigated metal oxide NPs production. Goswami et al. (2010) have studied the applications of different kinds of NPs, silver (SNP), aluminum oxide (ANP), zinc oxide, and titanium dioxide NPs in the insects' control. Some nanomaterials proved effective in mosquitoes co- 
ntrol such as nano-silica (Deanath et al, 2011; Barik et al, 2012), silver NPs (Marimuthu et al, 2011; Arjunan et al, 2012), and aluminum NPs (Stadler et al, 2010; 2017).

Nano-metal oxides such as $\mathrm{ZnO} \& \mathrm{Al}_{2} \mathrm{O}_{3}$ are promising materials due to their highly advantageous characteristics such as large surface area, small particle size and high chemical stability (Klabunde, 1996). These unique properties provide the ability of NPs to penetrate through exoskeleton and cause insect mortality (Benelli, 2016; Foldbjerg et al, 2015). Mostafa et al. (2018) showed that synthesized nano-oxides have a high mortality effect on larvae of $C x$. quinquefasciatus.

The present study aimed to evaluate the activity and penetration impact of fungus $M$. anisopliae, combined with the synthesized nano-metals $\mathrm{ZnO}$ and $\mathrm{Al}_{2} \mathrm{O}_{3}$, against the larvae of Cx. quinquefasciatus mosquitoes.

\section{Materials and Methods}

Mosquitoes rearing: Larvae of $C x$. quinquefasciatus were reared in the Chemistry and Biochemistry lab, Texas State University, San Marcos TX, USA (Mostafa et al, 2018) under laboratory conditions at $25 \pm 2^{\circ} \mathrm{C}, 80 \pm$ $5 \%$ relative humidity (R.H.) and photoperiod $14 \mathrm{~L}: 10 \mathrm{D}$. Adult mosquitoes were kept in cages $(40 \mathrm{~cm} \times 40 \mathrm{~cm} \times 40 \mathrm{~cm})$ and fed $10 \%$ glucose solution. While, the females laid eggs two days after a blood meal, egg rafts were collected in plastic bowls containing water and kept for hatching. Larvae were reared in plastic trays $(30 \mathrm{~cm} \times 25 \mathrm{~cm} \times 5 \mathrm{~cm})$ and fed on fish food.

Preparation of metal oxide nano-powder: Nano-metal oxides have been prepared by Co-precipitation method in Chemistry and Biochemistry lab, Texas State University, San Marcos TX. USA (Mostafa et al, 2018). To obtain $\mathrm{ZnO}$ and $\mathrm{Al}_{2} \mathrm{O}_{3}$ nano-powder the samples dried at $80^{\circ} \mathrm{C}$ for 24 hours followed by annealing at $500^{\circ} \mathrm{C}$ for 2 hours.

Fungal source and preparation of spore suspension: Entomopathogenic fungal cultures were obtained from Agriculture Research Service (ARSEF) in Ithaca New York, USA. M. anisopliae (Balsamo-Crivelli). The fung- al isolates were cultivated and maintained on Sabouraud Dextrose Agar yeast (SDAY) medium. Spores were harvested by scraping the culture surface with a sterile loop in 10 $\mathrm{ml}$ distilled water. A drop of $0.01 \%$ Tween 80 was added. Spore suspension was then filtered through muslin cloth to remove mycelia, and counted by using an improved Neubauer haemocytometer.

Larvicidal effect of fungus $M$. anisopliae alone and combined with NPs ( $\mathrm{ZnO} \&$ $\mathrm{Al}_{2} \mathrm{O}_{3}$ ) against $C x$. quinquefasciatus larvae: Four concentrations $\left(1.42 \times 10^{5}, 1.42 \times 10^{6}\right.$, $1.42 \times 10^{7} \& 1.42 \times 10^{8}$ spore $/ \mathrm{ml}$ ) of $M$. anisopliae were prepared. Spore suspension of each concentration was applied against $C x$. quinquefasciatus larval instars. The lowest concentration $\left(1.42 \times 10^{5}\right.$ spore $\left./ \mathrm{ml}\right)$ were tested with different concentrations $(5,10 \& 30$ $\mathrm{mg} / \mathrm{l})$ of NPs $\left(\mathrm{ZnO} \& \mathrm{Al}_{2} \mathrm{O}_{3}\right)$. For each case, larvae were divided into four replicates. Twenty larvae per replicate were transferred into $200 \mathrm{ml}$ sterilized water in $250-\mathrm{ml}$ plastic cups covered with mosquito's netting (Scholte et al, 2004). A group of larvae was treated with sterile water solution as control. All cups were maintained at $25 \pm 2{ }^{\circ} \mathrm{C}, 80 \pm 5 \%$ R. $\mathrm{H}$. and $14 \mathrm{~L}$ : $10 \mathrm{D}$ photoperiod. Mortality was observed daily for 14 days.

SEM: Infected larvae were prefixed in $2.5 \%$ glutaraldehyde (Sigma) for $2 \mathrm{hr}$, washed with $0.1 \mathrm{M}$ cacodylate buffer $(\mathrm{pH}$ 7.2) for about $15 \mathrm{~min}$ and then the specimens were post-fixed in $1 \%$ OsO4 in the same buffer for $1 \mathrm{hr}$. Furthermore, specimens were washed with buffer, dehydrated in ethanol series and treated in acetone solution. Specimens were sputter coated with Iridium and examined using Scanning Electron Microscope (Model, Helios Nano-lab. 400) at $10 \mathrm{KV}$.

Statistical analysis: Mortality data was analyzed with SPSS version 14. Using one-way analysis of variance (ANOVA) followed by pair wise comparisons based on Tukey's HSD tests. The results were expressed as means $( \pm \mathrm{SE})$ and mortality was corrected using Abbott's formula (1925). $\mathrm{LT}_{50}, \mathrm{LT}_{90}$ $\&$ their associated confidence intervals were 
estimated from regression analysis.

\section{Results}

$M$. anisopliae against $C x$. quinquefasciatus larvae showed significant concentrationdependent larval lethal effects i.e. as concentration increased, lethality also significantly increased. At concentrations of $1.42 \times 10^{5}$, $1.42 \times 10^{6}, 1.42 \times 10^{7}, 1.42 \times 10^{8}$ spore $/ \mathrm{ml}$, rates of the larval mortality was $80 \pm 0.98 \%$, $89.25 \pm 0.52 \%, 94.75 \pm 1.62 \%$ \& $100 \pm 0.0 \%$ respectively. As well, percentage of larval mortality was significantly affected by periods of exposure to the fungus, longer periods of exposure showed higher rates of mortality. At exposure periods of $1,3,5 \& 7$ days to fungal concentrations of $1.42 \times 10^{8}$ spore $/ \mathrm{ml}$, the mean larval mortality was $78.75 \pm 0.75 \%, \quad 83.25 \pm 0.65 \%, \quad 98.25 \pm 1.54 \%$ \& $100 \pm 0.0 \%$, respectively. The differences among rates of mortality were statistically significant $(\mathrm{F}=5.998 ; \mathrm{df}=3 ; \mathrm{P}<0.006)$. The $\mathrm{LT}_{50} \& \mathrm{LT}_{90}$ dramatically decreased with the increase of spore concentrations and periods of exposure (Tab.1). With spore concentrations of $1.42 \times 10^{5}, 1.42 \times 10^{6}$, $1.42 \times 10^{7}, 1.42 \times 10^{8}, L_{50}$ was calculated as $4.06,0.97,0.97 \& 0.54$ days, and $\mathrm{LT}_{90}$ as $8.18,7,5.65 \& 4.12$ days respectively.

Table 1: Efficacy of different spore concentrations of $M$. anisopliae (spore $/ \mathrm{ml}$ ) on larval instars of $C x$. quinquefasciatus

\begin{tabular}{|c|c|c|c|c|c|c|c|}
\hline \multirow{2}{*}{$\begin{array}{l}\text { (spore/ml) conidia } \\
\text { Concentration }\end{array}$} & \multicolumn{4}{|c|}{ Mean percentage of daily mortality (Mean \pm S.E.) } & \multirow{2}{*}{$\begin{array}{l}\mathrm{LT}_{50} \\
\text { (Days) }\end{array}$} & \multirow{2}{*}{$\begin{array}{l}\mathrm{LT}_{90} \\
\text { (Days) }\end{array}$} & \multirow{2}{*}{$\mathrm{R}^{2}$} \\
\hline & $\overline{1}$ & 3 & 5 & 7 & & & \\
\hline $1.42 \times 10^{5}$ & $31.25 \pm 1.06$ & $45 \pm 0.25$ & $70 \pm 1.47$ & $80 \pm 0.98$ & 4.06 & 8.18 & 0.986 \\
\hline $1.42 \times 10^{6}$ & $57.5 \pm 0.45$ & $72.25 \pm 1.76$ & $80 \pm 0.98$ & $89.25 \pm 0.52$ & 0.97 & 7 & 0.897 \\
\hline $1.42 \times 10^{7}$ & $67.5 \pm 0.75$ & $77.75 \pm 1.05$ & $86.25 \pm 0.62$ & $94.75 \pm 1.62$ & 0.97 & 5.65 & 0.789 \\
\hline $1.42 \times 10^{8}$ & $78.75 \pm 0.75$ & $83.25 \pm 0.65$ & $98.25 \pm 1.54$ & $100 \pm 0.0$ & 0.54 & 4.12 & 0.976 \\
\hline
\end{tabular}

$\mathrm{LT}_{50}, \mathrm{LT}_{90}$ lethal time caused $50 \%$ \& $90 \%$ larval mortality of $C x$. quinquefasciatus after exposure to spore concentration of $M$. anisopliae. $\mathrm{R}^{2}=$ Regression coefficient, S.E.: Standard Error.

In spite of the high activity of $M$. anisopliae against the $C x$. quinquefasciatus larvae (Tab. 1), addition of NPs $\left(\mathrm{ZnO} \& \mathrm{Al}_{2} \mathrm{O}_{3}\right)$ raised significantly the fungal activity by increasing larval mortality at shorter periods of exposure (Tab. 2). Combination of $M$. anisopliae $\left(1.42 \times 10^{5}\right.$ spore $\left./ \mathrm{ml}\right)$ with different concentrations $(30,10 \& 5 \mathrm{mg} / 1)$ of $\mathrm{ZnO}$, showed that the mean percentages of the larval mortality reached $100 \%, 86.25 \pm 1$ and
$80 \pm 1.08$, respectively, after 4 days of treatment (Fig. 2). As well, results of combination of $M$. anisopliae $\left(1.42 \times 10^{5}\right.$ spore $\left./ \mathrm{ml}\right)$ with $\mathrm{Al}_{2} \mathrm{O}_{3}$ of concentrations of $30,10 \& 5$ $\mathrm{mg} / \mathrm{l}$ showed mean larval mortality of $96.25 \%, 92.5 \pm 1.5 \% \& 77.5 \%$, respectively after 4 days of treatment. Combination effect of $M$. anisopliae with NPs of $\mathrm{ZnO} \& \mathrm{Al}_{2} \mathrm{O}_{3}$ against $C x$. quinquefasciatus larvae was shown (Tab. 2)

Table 2: Efficacy of M. anisopliae combined with NPs against the larval instars $C x$. quinquefasciatus

\begin{tabular}{|c|c|c|c|c|c|c|c|}
\hline \multirow{2}{*}{$\begin{array}{l}\text { Samples } \\
\text { NPs + Fungus }\end{array}$} & \multirow{2}{*}{$\begin{array}{c}\text { NPs }(\mathrm{mg} / \mathrm{l}) \\
\text { Concentrations }\end{array}$} & \multicolumn{4}{|c|}{ Mean percentage of mortality (Mean \pm S.E) } & \multirow{2}{*}{$\begin{array}{l}\mathrm{LT}_{50} \\
\text { (days) }\end{array}$} & \multirow{2}{*}{$\begin{array}{l}\mathrm{LT}_{90} \\
\text { (days) }\end{array}$} \\
\hline & & 1 & 2 & 3 & 4 & & \\
\hline \multirow{3}{*}{$\begin{array}{l}\mathrm{ZnO}+M . \\
\text { anisopliae }\end{array}$} & 5 & $45 \pm 0.50$ & $55 \pm 1.04$ & $67.5 \pm 0.70$ & $80 \pm 1.08$ & 1.86 & 5.08 \\
\hline & 10 & $46.25 \pm 0.41$ & $71.25 \pm 0.35$ & $78.75 \pm 0.28$ & $86.25 \pm 1.40$ & 1.65 & 4.11 \\
\hline & 30 & $82.5 \pm 0.65$ & $88.75 \pm 1.05$ & $95 \pm 0.75$ & $100 \pm 0.0$ & .31 & 2.07 \\
\hline \multirow{3}{*}{$\begin{array}{l}\mathrm{Al}_{2} \mathrm{O}_{3}+M . \\
\text { anisopliae }\end{array}$} & 5 & $38.75 \pm 1.05$ & $60 \pm 1.22$ & $75 \pm 1.28$ & $77.5 \pm 1.53$ & 1.88 & 5.60 \\
\hline & 10 & $53.75 \pm 1.40$ & $70 \pm 0.72$ & $85 \pm 0.77$ & $92.5 \pm 1.54$ & 1.01 & 3.94 \\
\hline & 30 & $66.25 \pm 1.47$ & $80 \pm 0.75$ & $91.25 \pm 0.25$ & $96.25 \pm 0.85$ & 0.89 & 3.02 \\
\hline
\end{tabular}

$\mathrm{LT}_{50}, \mathrm{LT}_{90}$ lethal time caused $50 \%$ \& $90 \%$ larval mortality after exposure to nanoparticle concentrations (mg/l) combined with fungus $M$. anisopliae, $\mathrm{P}<0.05$, Mean value of five replicates, (SE) stander error. Control (distilled water), nil mortality

$\mathrm{LT}_{50} \& \mathrm{LT}_{90}$ decreased with NPs addition and with the concentrations increase. Adding $\mathrm{ZnO} \mathrm{NPs}$ at concentrations of $30,10 \& 5$ $\mathrm{mg} / \mathrm{l}, \mathrm{LT}_{50}$ decreased to $1.86,1.65 \& 0.31$ days $\& \mathrm{LT}_{90}$ to $5.08,4.11 \& 2.07$ days, respectively. Adding $\mathrm{Al}_{2} \mathrm{O}_{3}, \mathrm{LT}_{50}$ decreased to $1.88,1.01 \& 0.89$ days $\& \mathrm{LT}_{90}$ to $5.60,3.94$ \& 3.02 days, respectively.
SEM for individual fungus and combined with NPs: Germination of M. anisopliae conidia was observed on dead larvae surface (Fig. 3); conidial germination was observed in a high density indicated by mycelium growth on the larval cuticle (Fig. 3a, b, \& c). Growth of mycelium and spor-es on respiratory siphons; blocked respiratory system and 
led to suffocation (Fig. 3d, e, \& f).

The $\mathrm{ZnO}$ NPs were detected on different body parts of larvae combined with the fungus, $M$. anisopliae that confirmed NPs have no antifungal effect. High density of $\mathrm{ZnO}$ nano-particles on insect abdominal cuticle with fungus, showed infected siphon openings \& gills with mycelium (Fig. 4, a, b, c, d, $\&$ e). So, fungus mycelium and spores with NPs destructed the respiratory system leading to suffocation and larval death.

After exposure of $C x$. quinquefasciatus larvae to $M$. anisopliae with $\mathrm{Al}_{2} \mathrm{O}_{3}$ NPs, SEM showed high density of $\mathrm{Al}_{2} \mathrm{O}_{3}$ NPs in abdominal region and germination of mycelium, and conidia in cuticle, confirmed the infection of siphons and gills with fungus $\&$ NPs of $\mathrm{Al}_{2} \mathrm{O}_{3}$ (Fig 5a, b, c, d, e \& f).

\section{Discussion}

In the present study, the insecticidal effect of $M$. anisopilae on $C x$. quinquefasciatus larvae caused significantly high percentage of larval mortality in short periods of time. These results agreed with Mnyon et al. (2010) who reported that $B$. bassiana and $M$. anisopliae fungal species were the commonest bio-control agents for African mosquito vectors. Furthermore, the results revealed that the entomopathogenic fungi attacked and invaded bodies' mosquito larvae that agreed with Amóra et al. (2010) and Benserradj and Mihoubi (2014) who found that some strains of $M$. anis-opliae were virulent against mosquito larvae.

In the present study, combination of $\mathrm{ZnO}$ \& $\mathrm{Al}_{2} \mathrm{O}_{3}$ NPs with entomopathogenic fungus, $M$. anisopilae had higher insecticidal effect at its lower concentration. M. anisopilae caused $100 \%$ \& $91.25 \%$ mortality in shorter period when combined with $\mathrm{ZnO} \&$ $\mathrm{Al}_{2} \mathrm{O}_{3} \mathrm{NPs}$, respectively. None showed advantages of synergistic interaction between metal oxide NPs and entomo-pathogenic fungi when applied simultaneously, but many studies fungi used in nanotechnology for producing NPs and showed larvicidal activity against mosquito larvae (Soni and Prakash, 2013; 2016). $\mathrm{ZnO} \& \mathrm{Al}_{2} \mathrm{O}_{3}$ NPs alone caused $96 \%$ \& $74 \%$ of larvae mortality, respectively in 14 days (Mostafa et al, 2018). Metal NPs proved effective against plant pathogens \& insect-pests. NPs were used in new formulations such as insecticides, and repellants (Barik et al, 2008; Owolade and Ogunleti, 2008; Gajbhiye et al, 2009; Goswami et al, 2010).

In the present study, SEM showed that the $M$. anisopliae spores were attached, invaded and germinated to $C x$. quinquefasciatus different parts of larval cuticle. Fungal growth was observed in different body parts after 48-72hr. High conidial germination density was observed on abdominal inter-segmental regions, on abdominal tracheae and on gills and respiratory siphons. These data were reported on mosquito larvae, fungal germination was seen on $C x$. quinquefasciatus larvae in contact with aqueous solution of $A s$ pergillus clavatus spores (Seye et al, 2009). Silva et al. (2004) showed that mosquito larvae treated with $M$. anisopliae had high amounts of conidial adhesion to colloid chitin with at least $90 \%$ germination after $24 \mathrm{hrs}$ incubation. Other possible routes of invasion were via respiratory siphon or alimentary canal (Lacey, 1988). $\mathrm{ZnO} \& \mathrm{Al}_{2} \mathrm{O}_{3} \mathrm{NPs}$ high density appeared in larval different body parts.

NPs may provide an alternative strategy to traditional broad-spectrum insecticides, to manage pests which have become resistant to conventional pesticides in integrated pest management programs (Korunic et al, 1999). SEM observations may support that larval death might be related to the effect of NPs on the cuticle wax layer, and the biotoxicity of NPs against mosquito larval instars may be related to the ability of NPs to penetrate through the exoskeleton (Benelli, 2016 and Foldbjerg et al, 2015). Larval death occurred via desiccation of insect cuticle by physicosorption of lipid, and damage in the cell membrane resulting in cell lysis and death of the insects. Also, Rouhani et al. (2012) proved the toxic effects of metal NPs (such as silver, zinc, aluminum, and titanium 
oxide) on plants, crustaceans, bacteria, fungi, pathogens and pests.

\section{Conclusion}

The current study revealed that combination of the insecticidal $M$. anisopliae fungi and nano-metal oxides $\mathrm{ZnO} \& \mathrm{Al}_{2} \mathrm{O}_{3}$ gave a great larvicidal effect against $C x$. quinque-fasciatus larvae through penetration of the exoskeleton leading eventually to insect death. Further study is needed to understand the mechanisms of how nanoparticles and entomopathogenic fungi interact and work together in controlling mosquito larvae.

The synthesized nano-metal oxides raised and accelerated entomopathogenic fungus, $M$. anisopliae activity against $C x$. quinquefasciatus larvae. Combination of synthesized nano-metal oxides with entomopathogenic $M$. anisopliae was recommended as an effective bio-control agent not only for $C x$. quinquefasciatus larvae but also for all mosquitos' vectors.

\section{References}

Abbott, WS, 1925: A method for computing the effectiveness of an insecticide. J. Econ. Entomol. 18:265-6.

Amóra, SSA, Bevilaqua, CML, Feijó, FMC, Pereira, RHMA, Alves, ND, et al, 2010: The effects of the fungus Metarhizium anisopliae var. acridum on different stages of Lutzomyia longipalpis (Diptera: Psychodidae). Acta Trop. 113:214-20.

Arjunan, NK, Murugan, K, Rejeeth, C, Madhiyazhagan, P, Barnard, DR, 2012: Green synthesis of silver nanoparticles for the control of mosquito vectors of malaria, filariasis, \& dengue. Vector-borne Zoonotic Dis. 12:262-8.

Barik, TK, Kamaraju, R, Gowasmi, A, 2012: Silica nanoparticles a potential new insecticide for mosquito vector control. Parasitol. Res. 111: 1075-83.

Barik, TK, Sahu, B, Swain, V, 2008: Nano-silica from medicine to pest control. Parasitol. Res. 103:253-8.

Benelli, G, 2016: Plant-mediated synthesis of nanoparticles: A newer and safer tool against mosquito-borne diseases? Asia-Pac. J. Trop.

Biomed. 6:353-4.

Benelli, G, Maggi, F, Pavela, R, Murugan, K, Govindarajan, M, et al, 2018: Mosquito con- trol with green nanopesticides: Towards the one health approach? a review of non-target effects. Environ. Sci. Poll. Res. https://doi.org/10.1007/s 11356-017-9752-4.

Benserradj, O, Mihoubi, I, 2014: Larvicidal activity of entomopathogenic fungi Metarhizium anisopliae against mosquito larvae in Algeria. Int. J. Curr. Microbiol. Appl. Sci. 3:54-62.

Bhattacharyya, A, Bhaumik, A, Rani, PU, Mandal, S, Epidi, TT, 2010: Nano-particles: A recent approach to insect pest control. Afr. J. Biotechnol. 9:3489-93.

CDC, 2012: West Nile Virus, Statistics, Surveillance, and Control Archive. Fort Collins, Colorado, USA: http://www.cdc.gov/ncidod/dvbid/ westnile/surv\&control.htm

Cetin, H, Yanikoglu, A, Cilek, JE, 2010: La-rvicidal activity of selected plant hydro distillate extracts against the house mosquito, Culex pipiens, a West Nile virus vector. Parasitol. Res. 108:943-8.

Deanath, N, Das, S, Seth, D, Chandra, R, Bhattacharya, SC, et al, 2011: Entomotoxic effect of silica nanoparticles against Sitophilus oryzae (L.). J. Pest Sci. 84:99-105.

Elnakib, MM, Abdel Fadil, EE, Morsy, TA, 2018: The arthropod-borne encephalitis viruses, the neglected serious diseases. J. Egypt. Soc. Parasitol. 48, 3:513-28.

Foldbjerg, R, Xiumei Jiang, X, Teodora Miclau, T, Chen, C, Autrup, H, et al, 2015: Silver nanoparticles-wolves in sheep's clothing? Toxicol. Res. 4: 563-75.

Gajbhiye, M, Kesharwani, J, Ingle, A, Gade, A, Rai, M, 2009: Fungus-mediated synthesis of silver nanoparticles and their activity against pathogenic fungi in combination with fluconazole. Nanomed. Nanotechnol. Biol. Med. 5:382-6.

Goswami, A, Roy, I, Sengupta, S, Debnath, N, 2010: Novel applications of solid and liquid formulations of nanoparticles against insect pests and pathogens. Thin Solid Films 519:1252-7.

Kirschbaum, JB, 1985: Potential implication of genetic engineering and other biotechnologies to insect control. Ann. Rev. Entomol. 30:51-70.

Klabunde, KJ, Stark, J, Koper, O, Mohs, C, Park, D, et al, 1996: Nano-crystals as stoichiometric reagents with unique surface chemistry. J. Phys. Chem. 100:12142-53.

Korunic, Z, Ormesher, P, 1999: Evaluation and standardized testing of diatomaceous earth. In: Jin, Z, Liang, Q, Liang, Y, Tan, X, Guan, L, (Eds.), Proceed. of the $7^{\text {th }}$ Intern. Working Conf. 
on Stored-Product Protection; 14-19 October 1998, Beijing, China; Sichuan Publishing House of Science \& Technology, Chengdu, China.

Lacey, CM, Lacey, LA, Roberts, DR, 1988: Route of invasion and histopathology of Metarhizium anisopliae in Culex quinquefasciatus. J. Invert. Pathol. 52:108-18.

Marimuthu, S, Rahman, AA, Rajakumar G, Bagavan, A, Zahir, AA, et al, 2011: Evaluation of green synthesized silver nanopesticides against parasites. Parasitol. Res. 108: 1541-9.

Mnyone, L, Kirby, M, Lwetoijera, D, Mpingwa, M, Simfukwe, E, et al, 2010: Tools for delivering entomopathogenic fungi to malaria mosquitoes: Effects of delivery surface on fungal efficacy and persistence. Malar. J. 9:246.

Mostafa, WA, Elgazzar, El, Beall, GW, Rashed, SS, Rashad, EM, 2018: Insecticidal effect of zinc oxide and aluminum oxide nanoparticles synthesized by co-precipitation technique on $\mathrm{Cu}$ lex quinquefasciatus larvae (Diptera: Culicidae). Inter. J. Appl. Res. 4:290-7.

Owolade, OF, Ogunleti, DO, 2008: Effects of titanium dioxide on the diseases, development and yield of edible cowpea. J. Plant Protect. Res. 48:329-36.

Rouhani, M, Samih, MS, Kalantari, S, 2012: Insecticidal effect of silver and zinc nanoparticles against Aphis nerii Boyer of fonscolombe (Hemiptera: Aphididae). Chilean J. Agric. Res.
72:590-594.

Scholte, EJ, Knols, BG, Samson, RA, Takken, W, 2004: Entomopathogenic fungi for mosquito control: A review. J. Insect Sci. 4:19-22.

Seye, F, Faye, O, Ndiaye, M, Njie E, Afoutou, J, 2009: Pathogenicity of the fungus, Aspergillus claviatus, isolated from the locust, Oedaleus senegalensis, against larvae of the mosquitoes Aedes aegypti, Anopheles gambiae, and Culex quinquefasciatus. J. Inst. Sci. 9:53-6.

Silva, RO, Silva, HH, Luz, C, 2004: Effect of Metarhizium anisopliae isolates originating from soil samples of the Central Brazilian Cerrado against Aedes aegypti larvae under laboratory conditions. Rev. Patol. Trop 33:207-16.

Soni, N, Prakash, S, 2013: Possible mosquito control by silver Nanoparticles synthesized by soil fungus (Aspergillus niger 2587). Adv. Nanopart. 2:125-32.

Soni, N, Prakash, S, 2016: Combinatorial efficacy of silver nanoparticles against mosquito larvae. SM J. Nanotechnol. Nanomed. 1, 1: 1001.

Stadler, T, Buteler, M, Weaver, DK, 2010: Nanoinsecticidas: Nuevas perspectivas para el control de plagas. Rev. Soc. Entomol. Argent. 69: $149-56$.

Stadler, T, Lopez-Garcia, GP, Gitto, JG, Buteler, M, 2017: Nanostructured alumina: biocidal properties and mechanism of action of a novel insecticide powder. Bull. Insectol. 70:17-25.

\section{Explanation of figures}

Fig. 1: Mean percentage of accumulative daily mortality of larval instars of $C x$. quinquefasciatus after exposed to different $M$. anisopliae concentrations.

Fig. 2: Mean percentage of accumulative daily mortality of larval instars of $C x$. quinquefasciatus after exposure to different metal oxide NPs concentrations combined with M. anisopliae. (a) $\mathrm{ZnO}+$ M. anisopliae (b) $\mathrm{Al2O}+M$. anisopliae.

Fig. 3: SEM of body surfaces (abdomen and respiratory siphon) of $2^{\text {nd }}$ larval instar of $C x$. quinquefasciatus infected with $M$. anisopliae. (a, b \& c) Infected abdominal and thoracic regions with the fungus, M. anisopliae (d, e and f) Infected respiratory siphons. (Abd: Abdomen, Co h: conidia head, Co ger: conidia germination, Myc.: Mycelium, Siph: siphon, Sp: spores).

Fig. 4: SEM of body surfaces (abdomen and respiratory siphon) of $2^{\text {nd }}$ larval instar of $C x$. quinquefasciatus infected with $M$. anisopliae and $\mathrm{ZnO}$ NPs. (a \& b) Infected abdominal and thoracic regions with combination of $\mathrm{ZnO}$ and $M$. anisopliae (c) Infected respiratory siphons. (d)Infected gills (Abd: Abdomen, Co h: conidia head, Co ger: conidia germination, Gill: gills, Myc.: Mycelium, Siph: siphon).

Fig. 5: SEM of body surfaces (abdomen and respiratory siphon) of $2^{\text {nd }}$ larval instar of Cx. quinquefasciatus infected with $M$. anisopliae and Al2O3 NPs. (a, b, c \& d) Infected abdominal and thoracic regions with combination of Al2O3 + M. anisopliae (e) Infected respiratory siphons. (f)Infected gills (Abd cu: Abdomen cuticle, Co ger: conidia germination, Gill: gills, Myc.: Mycelium, Siph: siphon, Sp: spores).

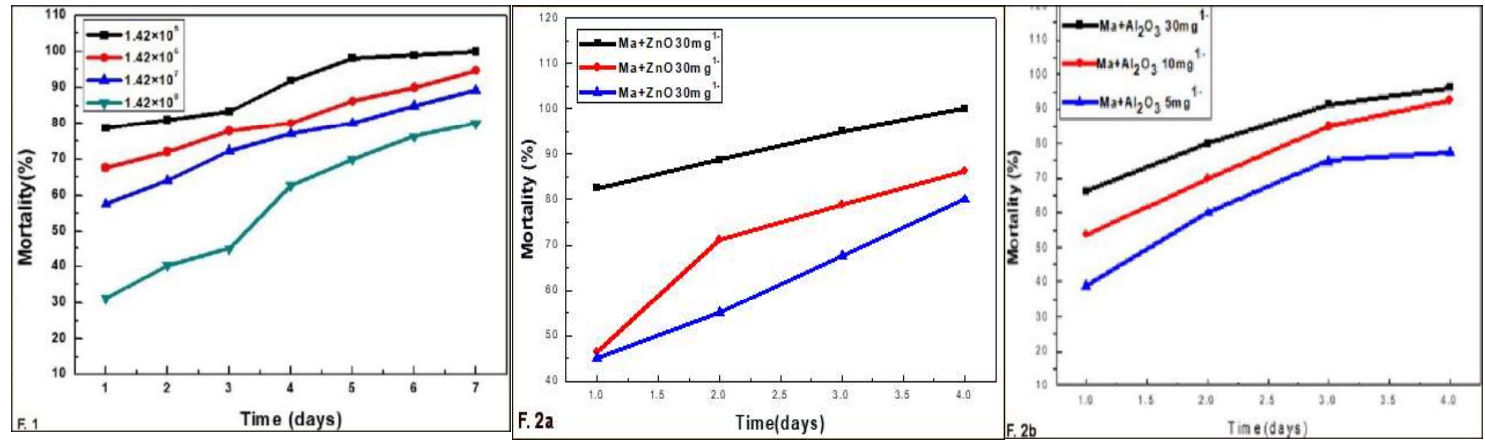



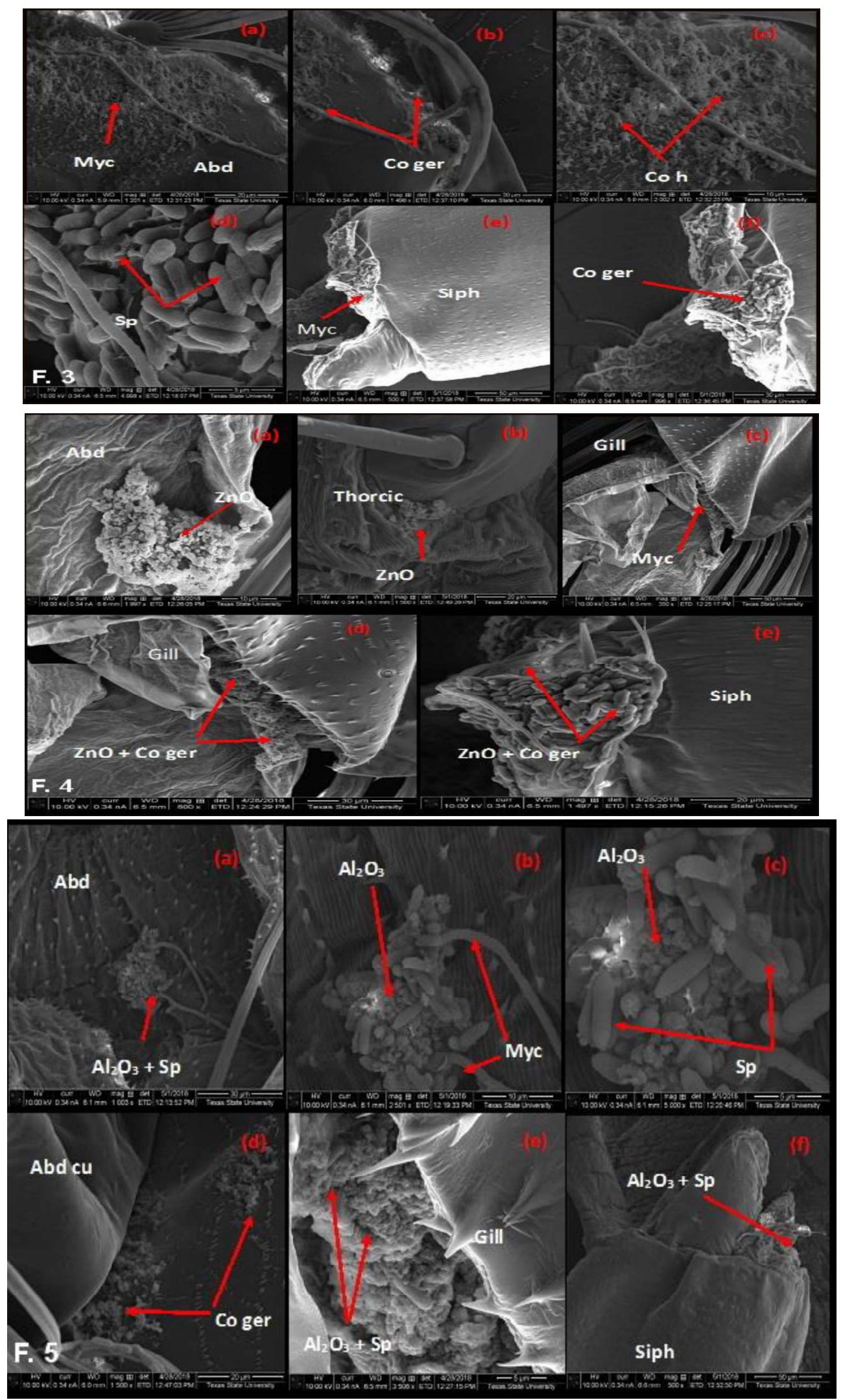